\title{
Students' Errors in the Use of Present Participle in Translating Simple Dialog at the Eleventh Grade of SMK Taruna Masmur Pekanbaru
}

\author{
Veby Aisyha Putri Irawan ${ }^{1}$, Drs. H. M. Syafi'i S, M. Pd ${ }^{2}$ \\ Faculty of Education and Teacher Training, \\ State Islamic University of Sultan Syarif Kasim Riau, \\ Pekanbaru, Riau, Indonesia \\ veby_aisyha@yahoo.com ${ }^{1}$, m.syafii.siec@gmail.com ${ }^{2}$
}

\begin{abstract}
The research proposed a formulation of the problem: what kinds of errors were produced in the use of present participle in translating simple dialog by the students at the eleventh grade of SMK Taruna Masmur Pekanbaru. The objective of the research was to explain the kinds of students' errors in the use of present participle in translating simple dialog at the eleventh grade students of SMK Taruna Masmur Pekanbaru. The research design is descriptive research. The population of this research was the eleventh grade students of SMK Taruna Masmur Pekanbaru in 2017/2018 academic year. It consisted of one class; the number of population was 14 students. The sample of this research was 14 students. The instrument of this research were test and documentation. The technique of analyzing data was quantitative analysis. Based on the data analysis, the researcher concluded that the percentage of all indicators were misformation (40 errors or $56.3 \%$ ), omission (17 errors or 23.9\%), addition (13 errors or 18.3\%), and misordering (1 error or $1.4 \%)$. From the data above the most common errors produced by the eleventh grade students of SMK Taruna Masmur Pekanbaru was misformation consisting of 40 errors or $56.3 \%$.
\end{abstract}

Keywords: Error, Present Participle

\section{INTRODUCTION}

Learning English is important because it is an international language which is used by people in the world in order to communicate. In learning English, there are four main skills that should be mastered by the learners,: speaking, writing, listening and reading. Writing plays an important role in ESL/EFL learning, as an essential skill, writing should be taught intensively at school. Writing has some components, they are content, organization, mechanics, vocabulary, and grammar.
In writing, the students learn how to write words, phrases, clauses, and sentences. When the students write a sentence, they should concern with the structure, because it is included into writing components which is grammar. One of the structures that the students always make errors is producing present participle. Although present participle has been taught since junior high school, the students still cannot produce it appropriately in a sentence. Because when the students make a sentence, they are influenced by overgeneralization. It causes most of them make errors on it. 
Based on the reality, some students are still difficult to produce present participle appropriately. Almost all of the students confront with errors in learning English in term of present participle. For instance, the use of verb ing for gerund and present participle. The students often fall into an assumption that to indicate a noun, an adjective, and a verb in sentences. The students often assume that all verbs adding with -ing at the end of the verb should be present progressive in which the action is happening and present participle is used. For example : my hobby is playing piano. Most students will infer that the action (playing) is happening, because they assume that each verb ending by -ing must be present progressive using present participle. Whereas it is gerund indicating a noun. Students' ability in producing present participle is still very far from the expectation of the curriculum. it can be proven by the researcher from students' $\mathrm{kkm}$ results. It can be found in $\mathrm{kkm}$.

Error is an essential part in learning any skill. The making of errors made by new language learners can not be avoided anymore, besides no one will learn without making them. Dulay (1982) defined errors as the flawed side of the learne's speech or writing. It means that they are parts of conversation or composition of writing that diverge from the rules of language.

SMK Taruna Masmur is a vocational school found in Pekanbaru as a formal education institution. It is located in Soekarno Hatta street. It uses k13 as its curriculum. The school provides English to its students. According to school based curriculum of SMK Taruna Masmur, it stated that:

Expressing the meaning in transactional conversation (to get things done) and interpersonal (to socialize) simply by using the variety of spoken language accurately, fluently to interact with surrounding environment which involves act and talk: asking for, giving, refusing merit, asking for, giving, refusing things, admitting, denying a fact, and asking for and giving opinion.

According to the quotation above, it is clear that students are expected to be able to express meaning of transactional conversation and interpersonal accurately and fluency. If the students can not master the accuracy of the language, as what has been demanded by the school base curriculum, so they can not reach the goal of the curriculum that is expressing meaning to interact with surrounding environment.

The the criteria of students' minimum passing grade of English subject is 85 of English subject. In order that the students can reach the minimum score in accordance to $\mathrm{kkm}$, the teacher arranges teaching and learning process as creatively as possible. For instance, the teacher gives some interesting pictures or videos to the students and asks them to share their idea about the pictures or the videos in front of their classmates. Then the teacher asks them to write the explanation or the description about the pictures or the videos by their words.

Based on the preliminary study at the school which was done by interviewing the English teacher, observing the teaching and learning process in the classroom, it showed that the students still make some errors when doing exercises about present participle even though their English teacher has explained the material clearly. According to the English teacher, he stated that some of the students often made errors in the use of present participle. For instance, they always wrote "I doing" instead of "I am doing", or "studing" instead of "studying". Some 
of the students were still confused when they should use present participle in a sentence and how to write the correct rule of it and it caused errors in their writing.

\section{LITERATURE REVIEW}

\section{a. Error Analysis}

Learning something needs process by which success will come by profiting from error. Learning foreign language is different with learning our mother tongue, because of that, it is possible for students to make an error, and error is difficult enough to avoid. According to Dulay et al (1982), errors are the flawed side of learner's speech or writing. They are those parts of conversation or composition that deviate from some selected norms of mature language performance. Error in learning new language is related to the learners' competence. Students make error because they are lack of understanding about target language, it will be led to the factor that students make mistakes and errors.

Error and mistake are two synonyms that have little same meanings, but in leaning language error and mistake are different. According to Brown (2007) A mistake refers to a performance error that is either a random guess or a slip, it is a failure to utilize a known system correctly.

Brown(2007) categories the source of error into interlingual transfer, intralingual transfer, context of learning and communication strategies.

1) Interlingual transfer is the negative influence of the first language. Before the learners get familiar with the second language system, they previously refer to the linguistic system of the first language.
2) Intralingual transfer is the negative transfer within the target language itself. In other words, the learners generalize the rules incorrectly within the target language.

3) Context of Learning is Context refers, for example, in a classroom with their teacher and materials in the case of school learning or the social situation in the case of untutored second language learning. In the classroom context, the teacher or the textbook can lead the learners to make faulty hypotheses about the language. In other words, the learners have wrong hypotheses of the teacher's explanation or the textbook which lead them to make errors.

4) Communication strategy is related to learning styles. Learners obviously use production strategies in order to enhance getting their messages across. However, at times these techniques can become a source of errors.

Norrish divides the cause of errors into three categories, those are Carelessness, First Language Interference and Translation which those are from the learners themselves or the teacher, and the method. And hubbard devided it into three different categories, those are mother-tongue interference, overgeneralization, errors encouraged by teaching material of method.

Some experts reveal their opinions of the goal of EA. According to Norrish (1983, p.80), "Error Analysis can give a picture of the type of learners' difficulties experienced by the learners. If it is carried out on a large scale such a survey, it can be helpful in drawing up a curriculum." It means that EA has significant to check the students ${ }^{6}$ difficulty in learning. 
Dulay et al (1982) classified error into four categories taxonomy error there are four types of taxonomy, namely: Error type based on linguistic category, Error type based on surface strategy taxonomy, Error types based on comparative of taxonomy, and Error types based on communicative effect taxonomy.

1) Omission

Dulay et.al, states that omission is characterized by the absence of an item that must appear in a wellformed utterance.

2) Addition

Addition errors are the opposite of omissions. This error is characterized by the presence of an item which must not appear in a well-formed utterance.

3) Misformation

Misformations errors are characterized by the use of the wrong form of the morpheme or structure.

4) Misordering

These errors are characterized by the incorrect placement of morpheme or group of morphemes in an utterance.

\section{b. Present Participle}

1) Definition.

Participle is a verb form commonly used with the combination of auxiliary verb to create continuous and perfect sentences. Swan (1995) stated in his book that -when verb-ing forms are used as verbs, adjectives, or adverbs, they are often called as present participle. When they are used as nouns, they are often called as gerunds. But, Swan stated that the distinction is not as simple as said.
2) The Use of Present Participle.

a. Participial Adjective

According to Azar (2009, p.236), she stated that present participle can be used as a modifier to convey an active meaning. The noun that is modified does something. For example :

It is a confusing problem.

b. Reduction of Adjective Clauses to Adjective Phrases

Azar (2009, p.294) stated that an adjective phrase is a reduction of an adjective clause. It will be a modifier of the noun. An adjective phrase does not consist of a subject and a verb. For example :

I know the girl who is talking to my mother (adjective clause)

I know the girl talking to my mother (adjective phrase)

c. The Progressive Tenses

According to Azar (2009, p.14) she stated that the progressive tenses means that the action is in the progress in particular time. The action of these tenses occurs before, is in the progress, and continues after another time or action.

There are 3 types of progressive tenses, they are : present progressive, past progressive, and future progressive.

d. Special Expressions Followed by the -Ing Form of a Verb

- Spend + expression of time or money +-ing

I have spent two hours studying math.

- Waste + expression of time or money +-ing

I wasted ten billion buying this motorcycle. 
- $\quad$ Sit + expression of place + -ing

The students sit in their chairs doing an exercise.

- Stand + expression of place + -ing She stands in front of her house waiting for her boyfriend.

e. Gerund

Gerunds may be used in place of nouns as the subject or the compliment of a sentence. For example: my hobby is reading Ambiguity in the Use of Participle. According to phythian (2012) if the sentence is preceded by participle, it must be connected with a proper subject. It means if there are 2 sentences with the same subject, the first sentence can be begun with no subject by beginning with participle, and the participle must be connected with a proper subject mentioned in the second sentence.

For example:

Coming late to the school, my teacher scolded me. Who is coming late? It must be "I", not the teacher. So that, "I" is the subject of participle (coming), so the sentence must be : coming late to the school, I was scolded by my teacher.

\section{METHOD}

This research was a descriptive research design which has only one variable. According to Tavakoli (2012, p. 160) he said that descriptive research is an investigation that provides a picture of a phenomenon as it naturally occurs, as opposed to studying the impacts of the phenomenon or intervention. According to Verma and Malick (2005 p.78) said that descriptive method is a method portraying the actual fact. It means that the researcher intends to describe the situations. Descriptive research attempts to look at individuals, groups, institutions, methods and materials in order to describe, compare, contrast, classify, analyze, and interpret the entities and the events that constitute their various fields of inquiry.

The location of this research was SMK Taruna Masmur Pekanbaru on Soekarno Hatta Street, Pekanbaru, Riau. This research was conducted in August 2018.

The subject of this research is the eleventh grade students of SMK Taruna Masmur Pekanbaru, consisted of 14 students.

The population of this study were all of the eleventh grade students of SMK Taruna Masmur Pekanbaru consisting of 14 students, in academic year 2018-2019.

The sample of this research were taken $100 \%$ of the population by using total population sampling technique. Population sampling technique sample is a non-probability sample that is selected based on characteristic of a population and the objective of the study, because the class of the eleventh grade was only one class and consisted of 14 students, the researcher took all students as her sample. In accordance with Arikunto (2006) he stated that if the population was homogeneous less than 100 people, the sample would be taken all.

In this research, the researcher used test and documentation. In the test, the researcher used translating dialog.

In analyzing the data, This research looked for the percentage of the total error. 


\section{FINDINGS AND DISCUSSION}

This research is used to obtain the percentage of students' errors in the use of present participle in translating simple dialog.

For the types of errors commonly made by the students, there were 17 omissions, 13 additions, 40 misformations, and 1 misorderings. The total number of the students' in producing present participle was 71 errors. misformation was the highest error and misorder was the lowest error made by the students. the most errors made by the eleventh grade students of SMK Taruna Masmur Pekanbaru were 10 , and the lowest errors were 2.

For the total number of error in each participle, there were The total number of errors made by the students in present continuous tense was 9 errors, consisting of 2 omissions or $22.2 \%, 6$ misformations or $66.6 \%$, and 1 misordering or $11.1 \%$.

The total number made by the students in Gerund was 49 errors consisting of 7 omission or $14.2 \%, 10$ addition or $20.4 \%$, and 32 misformation or $65.3 \%$.

The total number of errors made by the students in Participial Adjective was 7 errors consisting of 5 omission or $71.4 \%$, and 2 misformation or $28.5 \%$.

The total number of students' ambiguity errors was 2 errors consisting of 2 omission or $100 \%$.

The total number of students' errors in producing participle in infinitive forms was 4 errors consisting of 3 additions or $75 \%$ and 1 misformation or $25 \%$.

\section{CONCLUSION}

The researcher concluded that the highest until the lowest frequency and percentage errors made by the students derived from misformation (40 errors or $56.3 \%$ ), omission (17 errors or $23.9 \%$ ), addition (13 errors or $18.3 \%$ ), and misordering ( 1 error or $1.4 \%$ ).

The researcher concluded the percentage of the total errors in each participle from the highest to the lowest one. In present continuous tense, there were 9 errors, consisting of 2 omissions or $22.2 \%, 6$ misformations or $66.6 \%$, and 1 misordering or $11.1 \%$. In gerund, there were 49 errors consisting of 7 omission or $14.2 \%, 10$ addition or $20.4 \%$, and 32 misformation or $65.3 \%$. In participial adjective, there were 7 errors consisting of 5 omission or $71.4 \%$, and 2 misformation or $28.5 \%$. In students' ambiguity errors, there were 2 errors consisting of 2 omission or $100 \%$. In students' errors in producing participle in infinitive forms, there were 4 errors consisting of 3 additions or $75 \%$ and 1 misformation or $25 \%$.

\section{REFERENCES}

Fatwa, D. (2014). an error analysis in using verb-ing form. jakarta.

Feralia, M. (2014). An Error Analysis of The Use of Present Participle Form of the Sixth Semester Students of FKIP Universitas Bandar Lampung. Bandar lampung.

Krohn, r. (1986). English sentence structure. unitate state america: the university of michigan press.

Riyanto, s. (2011). the textbook of English grammar. yogyakarta: pustaka widyatama.

Johnson, Keith. (2008). An Introduction to Foreign Language Learning and Teaching Second Edition. Edinburgh: Pearson Longman.

Lightbown, Patsy M. and Spada, Nina. (2011). How Language are Learned. Third Edition. New York: Oxford University Press. 
Veby Aisyha Putri Irawan, Drs. H. M. Syafi'i S, M. Pd - Students' Errors in the Use....

Murphy, Raymond. (1994). English Grammar in Use. Second Edition. Cambridge: Cambridge University.

Norrish, John. (1983). Language Learners and Their Errors. London: The Macmillan Press.

Parrot, Martin. (2002). Task for Language Teachers. Cambridge: Cambridge University Press.

Raymond Murphy. (1994). English Grammar in Use, Cambridge: Cambridge University Press. 